\title{
SERUM CYSTATIN C IN ESTIMATING GLOMERULAR FILTRATION RATE
}

\author{
SERUMSKI CISTATIN C U PROCENI JAČINE GLOMERULSKE FILTRACIJE \\ Velibor Čabarkapa, Zoran Stošić, Mirjana Đerić, \\ Ljiljana Vučurević-Ristić, Radmila Žeravica, Branislava Ilinčić \\ Institute of Laboratory Medicine, Clinical Centre of Vojvodina, Novi Sad, Serbia
}

\begin{abstract}
Summary: Using serum cystatin $C$ in estimating glomerular filtration rate (GFR) has in recent times been recommended. A number of simple formulas for calculating GFR have been derived specifically from serum cystatin $C$ concentrations. The purpose of this study was to assess the significance of cystatin $\mathrm{C}$ and of the two most frequently applied of these formulas in estimating glomerular filtration rate compared to serum creatinine and its derived formulas for estimating glomerular filtration rate from creatinine concentrations. The study included 74 patients: 59 were in various stages of chronic renal insufficiency (divided into two subgroups: I with GFR $\geq 60$ $\mathrm{mL} / \mathrm{min} / 1.73 \mathrm{~m}^{2}$ and II with GFR $<60 \mathrm{~mL} / \mathrm{min} / 1.73 \mathrm{~m}^{2}$ ) and 15 on hemodialysis. A control group of 30 healthy participants was also included in the study. Serum values of cystatin $C$ ranged from: $0.86 \pm 0.16 \mathrm{mg} / \mathrm{L}$ in subgroup $\mathrm{I}$, and 1.77 $\pm 0.79 \mathrm{mg} / \mathrm{L}$ in subgroup II, to $6.9 \pm 1.83 \mathrm{mg} / \mathrm{L}$ in patients on hemodialysis. The correlation between the two formulas derived from cystatin $\mathrm{C}$ and the clearance of creatinine, as well as the Cockcroft and Gault's formula, was significant, while one of the formulas derived from cystatin $C$ did not show a significant correlation with MDRD. It was concluded that serum cystatin $C$ is a significant marker in estimating glomerular filtration rate, especially in the advanced stages of chronic renal insufficiency.
\end{abstract}

Keywords: cystatin C, Cockcroft-Gault formula, MDRD (Modification of Diet in Renal Disease), creatinine, glomerular filtration rate

\section{Introduction}

In clinical practice, estimating glomerular filtration rate (GFR) has proven to be the best indicator of renal function, and therefore the progression of renal illnesses as well (1). An endogenous substance that

Address for correspondence:

Dr Velibor Čabarkapa

Institute of Laboratory Medicine, Clinical Centre of Vojvodina Hajduk Veljkova 1, 21000 Novi Sad, Srbija

e-mail: veliborcabarkapa@nspoint.net
Kratak sadržaj: U novije vreme preporučena je upotreba serumskog cistatina $\mathrm{C}$ u proceni jačine glomerulske filtracije (GFR). Upravo iz serumske koncentracije cistatina $C$ je izvedeno nekoliko jednostavnih formula za izračunavanje GFR. Cilj ove studije je bio da proceni značaj cistatina $\mathrm{C}$ i dve najčešće primenjivane od tih formula u proceni jačine glomerulske filtracije u poređenju sa serumskim kreatininom i izvedenim formulama za procenu jačine glomerulske filtracije iz koncentracija kreatinina. $U$ studiju je uključeno 74 ispitanika: 59 u različitim stadijumima hronične bubrežne insuficijencije (podeljenih u dve podgrupe: I sa GFR $\geq 60 \mathrm{~mL} / \mathrm{min} / 1,73 \mathrm{~m}^{2}$ i || sa GFR $<60 \mathrm{~mL} / \mathrm{min} / 1,73 \mathrm{~m}^{2}$ ) i 15 na hemodijalizi. $U$ studiju je bila uključena i kontrolna grupa od 30 zdravih ispitanika. Serumske vrednosti cistatina $C$ su se kretale: $u$ podgrupi I $0,86 \pm 0,16 \mathrm{mg} / \mathrm{L}$, u podgrupi II 1,77 $\pm 0,79 \mathrm{mg} / \mathrm{L}$ i $\mathrm{kod}$ ispitanika na hemodijalizi $6,9 \pm 1,83 \mathrm{mg} / \mathrm{L}$. Korelacija između obe formule izvedene iz cistatina $C$ i klirensa kreatinina kao i Kokroft-Gaultove formule bila je značajna, dok jedna od ovih formuli izvedenih iz cistatina $C$ nije pokazala značajnu korelaciju sa MDRD. Može se zaključiti da je serumski cistatin C značajan parametar u proceni jačine glomerulske filtracije, naročito $\mathrm{u}$ odmaklim stadijumima hronične bubrežne insuficijencije.

Ključne reči: cistatin C, Kokroft-Gaultova formula, MDRD (modifikacije $u$ ishrani kod bubrežnih bolesti), kreatinin, jačina glomerulske filtracije

would meet the criteria of an ideal GFR indicator, should be produced at a constant rate within an organism, and should have its clearance performed exclusively by glomerular filtration, without additional

\footnotetext{
Abbreviations:

GFR - Glomerular filtration rate

$\mathrm{CrCl}$ - Creatinine clearance

C\&G - Cockcroft-Gault

MDRD - Modification of Diet in Renal Disease

CRI - Chronic renal insufficiency

$\mathrm{BMI}$ - Body mass index
} 
tubular secretion and/or reabsorption into the peritubular circulation. Concentrations of serum creatinine, as an endogenous substance, have been used in assessing renal function for some time. However, it has been known for a while that serum creatinine concentration is far from being an ideal indicator, since it is not only influenced by GFR, but other factors such as muscle mass, diet, gender, age and tubular secretion as well $(2,3)$. Certain substances, such as proteins, bilirubin and others, can also affect the accuracy of measurements made on serum creatinine (4). In addition to that, for purposes of estimating $\mathrm{GFR}$, creatinine clearance $(\mathrm{CrCl})$ is also in widespread clinical use today. But, this method's biggest limitation is the accuracy of twenty-four hour urine collection.

To overcome these difficulties, and in order to estimate GFR more accurately, efforts were made to derive formulas for calculating GFR, as well as $\mathrm{CrCl}$. In clinical practice, the most frequently used formulas are the Cockcroft-Gault (C\&G) formula (5), which yields absolute values of GFR expressed in $\mathrm{mL} / \mathrm{min}$ based on serum creatinine concentrations, body weight and age, and the MDRD (Modification of Diet in Renal Disease) formula, which yields relative values of GFR expressed in $\mathrm{mL} / \mathrm{min} / 1.73 \mathrm{~m}^{2}$ based on serum creatinine concentrations and age. Both of the formulas are affected by the patients' gender as well. These predictive equations are applicable to adults, whereas others are used in children, with the most widely used being the Schwartz and the CounahanBarrat formulas (6). Besides these, the C\&G and the MDRD formulas have other limitations: a) they are not the most suitable for estimating GFR in adults, b) the C\&G formula does not normalize the yielded creatinine clearance to a body surface of $1.73 \mathrm{~m}^{2}$. These formulas can underestimate GFR if it exceeds $60 \mathrm{~mL} / \mathrm{min} / 1.73 \mathrm{~m}^{2}$, or overestimate GFR if it is under $20 \mathrm{~mL} / \mathrm{min} / 1.73 \mathrm{~m}^{2}$, or if nephrotic-range proteinuria is present $(7-11)$.

In recent years a lot of attention has been given to cystatin $C$ as a potentially new substance that could be used in estimating GFR. Herget et al. (12) have made a recommendation about using particular GFR indicators in various stages of chronic renal insufficiency (CRI). According to this recommendation, cystatin C has been categorized as the leading indicator in estimating renal function at creatinine clearance levels of $60-90 \mathrm{~mL} / \mathrm{min} / 1.73 \mathrm{~m}^{2}$, while at creatinine clearance levels of $30-60 \mathrm{~mL} / \mathrm{min} / 1.73 \mathrm{~m}^{2}$, formulas derived from creatinine (the C\&G and the MDRD formulas for adults, and the Schwartz formula for children) and serum cystatin $C$ concentration if the patient is overweight $\left(\mathrm{BMI}>30 \mathrm{~kg} / \mathrm{m}^{2}\right)$ or if nephrotic-range proteinuria is present, are recommended. At creatinine clearance levels below $20 \mathrm{~mL} / \mathrm{min} / 1.73 \mathrm{~m}^{2}$ an average between creatinine clearance and urea clearance should be used. For acute renal dysfunction, cystatin $C$ was also recommended as the leading marker.
Cystatin $C$ is a protein of low molecular mass and belongs to the cysteine protease inhibitor group. It is produced at a constant rate by all cells with a nucleus. Considering its low molecular weight, it is freely filtrated through the glomeruli (13) with over $99 \%$ of the cystatin C filtrated that way being taken over by tubular cells, mostly by means of the receptor megaline, and dissolved there (14). That is exactly the reason why the daily excretion of cystatin C through urine is extremely low: $0.0074 \pm 0.0034$ $\mathrm{mg} / \mathrm{L}(15)$. The production of cystatin $C$ is influenced by very high doses of corticosteroids (16), as well as thyroid dysfunction (17). Cystatin C levels are lower in hypothyreosis, and higher in hyperthyreosis, compared to the levels in euthyroid state. An estimate of the function of the thyroid gland is therefore necessary before determining GFR based on cystatin C. Determining cystatin $C$ levels to estimate GFR is very useful for persons with reduced muscle mass or those undergoing quick changes in their muscle mass (children and elderly persons), because unlike creatinine, the serum cystatin $\mathrm{C}$ concentration remains constant between the ages of 1 and $50(18,19)$. There are no statistically significant differences between men and women when serum cystatin $C$ concentrations are concerned (15). What is more, cystatin $C$ has an important role in monitoring allograft function in persons who have undergone kidney transplantation, although it is still unclear whether cystatin $C$ has any advantages to serum creatinine and/or the derived formulas for estimating GFR (20).

Glomerular filtration rate can be calculated by applying predictive equations based on serum cystatin $C$ concentration. The aim of this paper was to determine the significance of different predictive formulas derived from cystatin $C$ and used for calculating GFR, and to compare them to the predictive formulas derived from serum creatinine concentrations for calculating GFR, as well as creatinine clearance determined using standard biochemical methods.

\section{Materials and Methods}

This prospective study included 104 participants, with their characteristics shown in Table $I$.

The participants in Group 1 and Group 2 were patients suffering from CRI who had been treated at the Department for Nuclear Medicine of the Clinical Center of Vojvodina for purposes of renal function tests.

Serum creatinine and serum urea concentrations, as well as concentrations of creatinine in urine were determined using standard methods on an Olympus AU400 biochemical analyzer and commercial sets produced by Olympus. The calculated values of $\mathrm{CrCl}$ were normalized relative to a body surface of $1.73 \mathrm{~m}^{2}$. 
Table I Subjects features.

\begin{tabular}{|c|c|c|c|c|}
\hline & I group & II group & III group & \\
\hline Subjects & GFR $>60 \mathrm{~mL} / \mathrm{min} / 1.73 \mathrm{~m}^{2}$ & $\mathrm{GFR}<60 \mathrm{~mL} / \mathrm{min} / 1.73 \mathrm{~m}^{2}$ & Hemodialysis & Control group \\
\hline Number $(f / m)$ & $13 / 13$ & $12 / 21$ & $7 / 8$ & $20 / 10$ \\
\hline Age & $51.2 \pm 12.4$ & $65.1 \pm 10.6$ & $47.3 \pm 10.8$ & $46.9 \pm 13.7$ \\
\hline Creatinine $(\mu \mathrm{mol} / \mathrm{L})$ & $100.5 \pm 22.2$ & $202.8 \pm 128.1$ & $1023.5 \pm 202.6$ & $81.4 \pm 14.1$ \\
\hline Urea $(\mathrm{mmol} / \mathrm{L})$ & $6.3 \pm 2.5$ & $10.6 \pm 3.7$ & $32.2 \pm 6.8$ & $4.59 \pm 1.68$ \\
\hline Creatinine clearance $\left(\mathrm{mL} / \mathrm{min} / 1,73 \mathrm{~m}^{2}\right)$ & $78.9 \pm 15.8$ & $34.1 \pm 15.2$ & - & $100.6 \pm 16.6$ \\
\hline Cockcroft-Gault formula/1,73 $\mathrm{m}^{2}$ & $64.2 \pm 15.3$ & $36.1 \pm 14.9$ & - & - \\
\hline $\operatorname{MDRD}\left(\mathrm{mL} / \mathrm{min} / 1,73 \mathrm{~m}^{2}\right)$ & $73.4 \pm 20.1$ & $38.6 \pm 16.2$ & - & - \\
\hline Cystatin C (mg/L) & $0.86 \pm 0.16$ & $1.77 \pm 0.79$ & $6.9 \pm 1.83$ & $0.67 \pm 0.11$ \\
\hline Formula I & $110.2 \pm 27.5$ & $45.8 \pm 24.8$ & - & - \\
\hline Formula II & $91.5 \pm 15.7$ & $48.6 \pm 19.1$ & - & - \\
\hline
\end{tabular}

Legend: GFR - glomerular filtration rate, MDRD - modification of diet in renal disease, Formula I: GFR $\left(\mathrm{mL} / \mathrm{min} / 1.73 \mathrm{~m}^{2}\right)=84.69 \times$ [cystatin C (mg/L) $]^{-1.68}$, Formula II: GFR $\left(\mathrm{mL} / \mathrm{min} / 1.73 \mathrm{~m}^{2}\right)=80.35 \times[1 /$ cystatin C $(\mathrm{mg} / \mathrm{L})]-4,3$

Serum cystatin $C$ concentrations were determined immunoturbidimetrically on the same biochemical analyzer using commercial sets produced by the DakoCytomation Company (Denmark).

The Cockcroft-Gault formula used for calculating creatinine clearance was the following one:

$\mathrm{Ccr}(\mathrm{mL} / \mathrm{min})=[(140-$ years of age $) \times$ body mass $(\mathrm{kg})] /[0.81 \times \mathrm{Scr}] \times[0.85$ if female $]$,

where $\mathrm{Ccr}$ - creatinine clearance, $\mathrm{Scr}$ - serum creatinine in $\mu \mathrm{mol} / \mathrm{L}$.

The resulting creatinine clearance was then normalized to a surface of $1.73 \mathrm{~m}^{2}$, using the following formula for calculating body surface:

$$
\mathrm{BS}=(\mathrm{BM} \times \mathrm{BH})^{1 / 2} / 60
$$

where $\mathrm{BS}$ - body surface in $\mathrm{m}^{2}, \mathrm{BM}$ - body mass in $\mathrm{kg}, \mathrm{BH}$ - body height in $\mathrm{cm}$.

The MDRD equation used was the following one:

$\mathrm{GFR}=32.788 \times(\mathrm{Scr})^{-1.154} \times$ (years of age $)^{-0.203} \times(0.742$ if female $)$

GFR - glomerular filtration rate in $\mathrm{mL} / \mathrm{min} /$ $1.73 \mathrm{~m}^{2}, \mathrm{Scr}-$ serum creatinine in $\mu \mathrm{mol} / \mathrm{L}$.

Two predictive equations for calculating GFR based on serum cystatin $C$ concentration were used and compared (6):

GFR $\left(\mathrm{mL} / \mathrm{min} / 1.73 \mathrm{~m}^{2}\right)=84.69 \times[$ cystatin C (in $\mathrm{mg} / \mathrm{L}$ ) $]^{-1.68}$ and

GFR $\left(\mathrm{mL} / \mathrm{min} / 1.73 \mathrm{~m}^{2}\right)=80.35 \times[1 /$ cystatin C (mg/l) ]-4.3

\section{Statistics}

Statistical processing was done using Microsoft Office Excel 2003 software package. The results were shown as averages \pm SD. Statistical methods applied were: f-test, t-test, correlation and linear regression analysis.

\section{Results}

Figure I shows the number of participants with elevated levels of serum cystatin $C$ and creatinine per group.

Averages of cystatin $C$ per group displayed statistically significant differences between all of the groups with $p<0.001$, apart from Group I and the

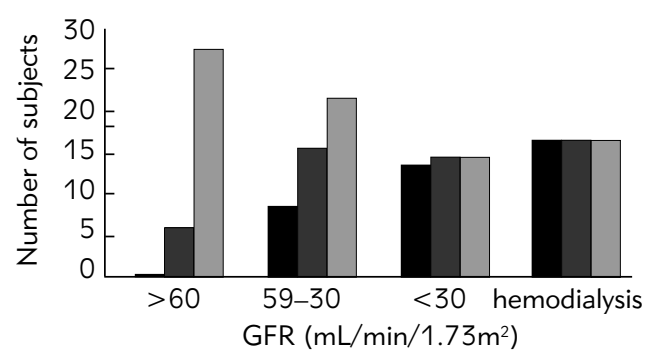

subjects with high cystatin C

subjects with high creatinine

overall number of subjects

Legend: GFR - glomerular filtration rate

Figure 1 Review of subjects with high serum concentrations of cystatin $\mathrm{C}$ and creatinine. 
Table II Number of subjects according to exception between GFR formulas from cystatin C and formulas for calculating creatinine clearance namely GFR $\left(\mathrm{mL} / \mathrm{min} / 1.73 \mathrm{~m}^{2}\right)$ in both groups.

\begin{tabular}{|l|c|c|c|c|c|c|}
\hline & \multicolumn{3}{|c|}{ Formula I } & \multicolumn{3}{c|}{ Formula II } \\
\hline Exception (mL/min) & $<10$ & $10-20$ & $>20$ & $<10$ & $10-20$ & $>20$ \\
\hline Creatinine clearance & $4 / 11$ & $6 / 10$ & $16 / 12$ & $10 / 10$ & $7 / 10$ & $9 / 13$ \\
\hline Cockcroft-Gault formula/1.73m² & $1 / 12$ & $4 / 11$ & $21 / 10$ & $3 / 13$ & $6 / 12$ & $16 / 8$ \\
\hline MDRD & $7 / 12$ & $2 / 10$ & $17 / 11$ & $5 / 13$ & $8 / 9$ & $13 / 11$ \\
\hline
\end{tabular}

Legend: Formula I: GFR $\left(\mathrm{mL} / \mathrm{min} / 1.73 \mathrm{~m}^{2}\right)=84.69 \times[\text { cystatin } \mathrm{C}(\mathrm{mg} / \mathrm{l})]^{-1,68}$ Formula II: GFR $\left(\mathrm{mL} / \mathrm{min} / 1.73 \mathrm{~m}^{2}\right)=80.35 \times 1 /$ cystatin C $(\mathrm{mg} / \mathrm{L})]$ - 4.3; Cockcroft-Gault formula/1.73 $\mathrm{m}^{2}$ - Cockcroft-Gault formula normalizing according to surface of $1.73 \mathrm{~m}^{2}$.

control group, in which $p<0.01$. Using regression analysis, high inverse correlations between serum cystatin $\mathrm{C}$ concentration and $\mathrm{CrCl}(r=-0.74$, $\mathrm{p}<0.001)$, between cystatin $C$ and MDRD $(r=$ $-0.69, p<0.001)$, and between cystatin $C$ and the C\&G formula corrected for a surface of $1.73 \mathrm{~m}^{2}(r=$ $-0.87, p<0.001)$ were determined. There was also a high correlation between serum creatinine and cystatin $C(r=0.75, p<0.001)$. The level of correlation between serum creatinine and $\mathrm{CrCl}$ was high $(r=$ $-0.69, \mathrm{p}<0.001$ ).

Between equation I for calculating GFR from serum cystatin $\mathrm{C}$ concentration, and $\mathrm{CrCl}$, there was a significant correlation in participants from Group 1 $(r=0.45, p=0.02)$, as in comparison with MDRD $(r=0.42, p=0.03)$ and the C\&G formulas $(r=0.44$, $p=0.02)$. Equation II exhibited a similar correlation to the one of equation I: relative to $\mathrm{CrCl}(r=0.47, p=$ $0.015)$, relative to MDRD $(r=0.42, p=0.03)$, and relative to $C \& G(r=0.44, p=0.02)$. In this group of participants there was a significant correlation between $\mathrm{CrCl}$ and serum creatinine $(r=-0.47, p=0.014)$ and serum cystatin $C(r=-0.46, p=0.0016)$.

In participants from Group 2 there was a significant correlation between equation I for calculating GFR from serum cystatin $\mathrm{C}$ concentration and $\mathrm{CrCl}$ $(r=0.58, p<0.001)$, just as compared to the C\&G formula ( $r=0.57, p<0.001)$, but not compared to MDRD ( $r=0.29, p>0.05)$. Equation II showed a somewhat higher correlation relative to $\mathrm{CrCl}(r=$ $0.63, p<0.0001)$ and the $C \& G$ equation $(r=0.59$, $\mathrm{p}<0.001)$, while in relation to MDRD a significant correlation did not occur ( $r=0.26, p=0.14)$. Between $\mathrm{CrCl}$ and serum creatinine concentration in this group there was a high correlation $(r=0.77$, $\mathrm{p}<0.001$ ), with a slightly lower, but still significant correlation occurring between $\mathrm{CrCl}$ and cystatin $\mathrm{C}$ (0.65, $\mathrm{p}<0.001)$.

Looking at all the participants with CRI (apart from the ones on dialysis), between equation I and $\mathrm{CrCl}$ there was a high correlation $(r=0.83$, $p<0.0001)$, as when comparing it to the C\&G formula $(r=0.78, p<0.001)$ as well as MDRD $(r=$
0.63, $\mathrm{p}<0.001)$. Between equation $\mathrm{II}$ and $\mathrm{CrCl}$ the correlation was also high $(r=0.84, p<0.0001)$, as well as when this equation was compared to the $C \& G$ formula $(r=0.77, p<0.001)$, and to MDRD ( $r=$ $0.64, p<0.001)$.

The number of participants compared to the discrepancies between the formulas for calculating GFR from serum cystatin $C$ concentration and formulas for calculating creatinine clearance and thereby GFR (expressed in $\mathrm{mL} / \mathrm{min} / 1.73 \mathrm{~m}^{2}$ ) in Groups 1 and 2, is shown in Table II. In all these cases the values resulting from formulas based on cystatin $\mathrm{C}$ concentration were higher than the values based on $\mathrm{CrCl}$, $C \& G$ and MDRD.

\section{Discussion}

One of the relatively new markers, which has been in use for more than two decades for estimating GFR, is cystatin C (1), since it not only meets certain criteria for being an »ideal « marker, but its determination is also very simple. A great number of studies have been done to emphasize the role of specifically cystatin $\mathrm{C}$ as the leading marker in the beginning stages of CRI (with creatinine clearance between 61 and $\left.90 \mathrm{~mL} / \mathrm{min} / 1.73 \mathrm{~m}^{2}\right)(21-23)$. Studies of $X u$ et al. (24) have shown high inverse correlation between serum cystatin $C$ and creatinine clearance $(r=-0.876)$. Our study also resulted in a high inverse correlation between serum cystatin $C$ and creatinine clearance $(r$ $=-0.74)$, with serum cystatin $C$ concentration within reference values in all patients with creatinine clearance above $60 \mathrm{~mL} / \mathrm{min} / 1.73 \mathrm{~m}^{2}$. Out of all the equations used, equation I exhibited a significant correlation with creatinine clearance $(p=0.02)$, the Cockcroft-Gault ( $=0.02)$ and MDRD ( $p=0.03)$, with a similar correlation occurring between equation II and other GFR indicators. In this group of participants the discrepancies of more than $20 \mathrm{~mL} / \mathrm{min}$ between equation I and other methods happened in about $61 \%$ of the cases comparing to creatinine clearance, in about $80 \%$ of the cases comparing to the Cockcroft-Gault equation, and in about $65 \%$ of the cases comparing to MDRD. The discrepancies 
were significantly lower for equation II, which therefore favored it for this group of participants.

In the group of participants with GFR $<60 \mathrm{~mL} /$ $\mathrm{min} / 1.73 \mathrm{~m}^{2}$ both of the equations derived from serum cystatin $C$ have shown a significant correlation with creatinine clearance and the Cockcroft-Gault formula (with slightly higher levels for equation II), but neither equation exhibited a significant correlation with MDRD. With this group of participants the discrepancies of more than $20 \mathrm{~mL} / \mathrm{min}$ between equation I and the other methods occurred in about $46 \%$ of the cases comparing to creatinine clearance, in about $38 \%$ of the cases comparing to the Cockcroft-Gault equation, and in about $42 \%$ of the cases comparing to MDRD. Similar discrepancies occurred for equation II.

When looking at participants from both groups, a high level of correlation is present between predictive equations derived from cystatin $\mathrm{C}$ and $\mathrm{CrCl}(\mathrm{r}=$ 0.83 for equation $\mathrm{I}$, and $\mathrm{r}=0.84$ for equation II), the $C \& G$ equation $(r=0.78$ for equation $\mathrm{I}$, and $r=0.77$ for equation II), and MDRD ( $r=0.63$ for equation I, and $r=0.64$ for equation II).

The data from comparisons of serum cystatin C, serum creatinine, and creatinine clearance calculated from the C\&G and MDRD formulas are in contradiction (25-27). Grubb et al. (28) have shown that equations based on cystatin $C$ have a higher precision in estimating GFR than the C\&G formula. Hoeck et al. (27) in their study show that serum cystatin $C$ and creatinine clearance calculated from the C\&G formula yield a higher diagnostic accuracy than serum creatinine, but a significant difference in the diagnostic accuracy between serum cystatin $C$ and creatinine clearance calculated from the C\&G formula was not determined. Although some studies have detected early changes in serum cystatin $C$ rather than creati-

\section{References}

1. Uzun H, Keles MO, Ataman R, Aydin S, Kalender B, Uslu E, et al. Serum cystatin $C$ level as a potentially good marker for impaired kidney function. Clin Bichem 2005; 38: 792-8.

2. Perrone RD, Madias NE, Levey AS. Serum creatinine as an index of renal function: new insights into old concepts. Clin Chem 1992; 38: 1933-53.

3. Levey AS, Coresh J. K/DOQI clinical practice guidelines on chronic kidney disease. Guideline 4. Estimation of GFR. Am J Kidney Dis 2002; 39 (Suppl 1): 76-92.

4. Weber JA, Van Zanten AP. Interference in current methods for measurement of creatinine. Clin Chem 1991; 37: 695-700.

5. Cockcroft DW, Gault MH. Prediction of creatinine clearance from serum creatinine. Nephron 1976; 16: $31-41$. nine in beginning kidney damage, other studies have not been able to confirm that (29). In a study by Donady et al. (25) a significant difference in diagnostic accuracy between serum cystatin $C$ and serum creatinine was not discovered, while a study by Kyhse-Andersen et al. (26) that included patients with $\mathrm{GFR}<80 \mathrm{~mL} / \mathrm{min} / 1.73 \mathrm{~m}^{2}$, discovered a significantly higher correlation of cystatin C and GFR determined by iohexol clearance than with serum creatinine, which led to the conclusion that cystatin $C$ had a higher diagnostic precision in estimating GFR reduction compared to serum creatinine. A study by Hoys et al. (30) did not find a significant difference in the diagnostic accuracy between serum cystatin $C$ and creatinine clearance calculated from the MDRD formula.

In our study, although serum concentrations of cystatin $C$ were within reference values in all participants with creatinine clearance $\geq 60 \mathrm{~mL} / \mathrm{min} /$ $1.73 \mathrm{~m}^{2}$, in 4 of the participants $(\sim 15 \%)$ the serum creatinine concentrations were elevated. In participants with creatinine clearance $<60 \mathrm{~mL} / \mathrm{min} / 1.73$ $\mathrm{m}^{2}, 27(\sim 82 \%)$ had elevated creatinine levels, while 19 ( $58 \%)$ had elevated cystatin $C$ levels.

The results of our study indicate that determining cystatin $C$ has no significant advantage for estimating GFR compared to creatinine, or creatinine clearance in the group of participants with relatively preserved renal function reserve. However, in the group of participants with a distinct renal function reserve reduction (GFR $<30 \mathrm{~mL} / \mathrm{min} / 1.73 \mathrm{~m}^{2}$ ), determining serum cystatin $C$ reflects the level of the reduction with more reliability, since the additional factors that could interfere in particular with determining cystatin $\mathrm{C}$ are a lot fewer in the advanced stages of chronic renal insufficiency than is the case with creatinine.

6. Dajak M, Ignjatović S, Majkić-Singh N. Renal function estimation of glomerular filtration rate. Journal of Medical Biochemistry 2007; 26: 51-7.

7. Bostom G, Kronenberg F, Ritz E. Predictive performance of renal function equations for patients with chronic kidney disease and normal serum creatinine levels. J Am Soc Nephrol 2002; 13: 2140-44.

8. Rule AD, Larson TS, Bergstralh EJ, Slezak JM, Jacobsen SJ, Cosio FG. Using serum creatinine to estimate glomerular filtration rate: accuracy in good health and in chronic kidney disease. Ann Intern Med 2004; 141: 929-37.

9. Poggio ED, Nef PC, Wang X, Greene T, Van Lente T, Dennis VW. Performance of the Cockcroft-Gault and modification of diet in renal disease equations in estimating GFR in ill hospitalized patients. Am J Kidney Dis 2005; 46: 242- 52. 
10. Branten AJ, Vervoort G, Wetzels JF. Serum creatinine is a poor marker of GFR in nephrotic syndrome. Nephrol Dial Transplant 2005; 20: 707-11.

11. Rule AD, Gussak HM, Pond GR, Bergstrahl EJ, Stegall MD, Cosio FG, et al. Measured and estimated GFR in healthy potential kidney donors. Am J Kidney Dis 2004; 43: 112-9.

12. Herget-Rosenthal S, Bökenkamp A, Hofman W. How to estimate GFR-serum creatinine, serum cystatin $C$ or equations? Clin Biochem 2007; 40: 153-61.

13. Filler G, Bökenkamp A, Hofman W, Le Bricon T, Marinez-Bru C, Grubb A. Cystatin C as a marker of GFRhistory, indications, and future research. Clin Biochem 2005; 38: 1-8.

14. Jacobsson $B$, Lignelid $H$, Bergerheim US. Transthyretin and cystatin $\mathrm{C}$ are catabolized in proximal tubular epithelial cells and the proteins are not useful as markers for renal cell carcinomas. Histopathology 1995; 26: 559-64.

15. Obrenović R, Petrović D, Majkić-Singh N, Trbojević J, Stojimirović B. Influence of proteinuria on cystatin C serum concentration in patients with primary glomerulonephritis. Jug Med Biohem 2006; 25: 21-5.

16. Risch L, Herklotz R, Blumberg A, Huber AR. Effects of glucocorticoid immunosuppression on serum cystatin $C$ concentrations in renal transplant patients. Clin $\mathrm{Chem}$ 2001; 47: 2055-9.

17. Fricker M, Wiesli P, Brandle M, Schwegler B, Schmid C. Impact of thyroid dysfunction on serum cystatin $C$. Kidney Int 2003; 63: 1944-7.

18. Harmoinen A, Ylinen E, Ala-Houhala M, Janas M, Kaila $M$, Kouri T. Reference intervals for cystatin $C$ in preand full-term infants and children. Pediatr Nephrol 2000; 15: 105-8.

19. Fischbach $M$, Graff $V$, Terzic J, Bergère $V$, Oudet $M$, Hamel G. Impact of age on reference values for serum concentration of cystatin $\mathrm{C}$ in children. Pediatr Nephrol 2002; 17: 104-6.

20. Herget-Rosenthal S, Trabold S, Huesing J, Heemann U, Philipp T, Kribben A. Cystatin C - An accurate marker of glomerular filtration rate after renal transplantation? Transpl Int 2000; 13: 285-9.

21. Newman DJ, Thakkar H, Edwards RG, Wilkie M, White $T$, Grubb $A O$, et al. Serum cystatin $C$ measured by automated immunoassay: a more sensitive marker of changes in GFR than serum creatinine. Kidney Int 1995; 47: 312-6.

22. Poege U, Stoschus B, Stoffel-Wagner B, Gerhardt T, Klehr HU, Sauerbruch T, et al. Cystatin $C$ as an endogenous marker of glomerular filtration rate in renal transplant patients. Kidney Blood Press Res 2003; 26: 55-60.

23. Dharnidharka VR, Kwon C, Stevens G. Serum cystatin $C$ is superior to serum creatinine as a marker of kidney function: a meta-analysis. Am J Kidney Dis 2002; 40: 221-6.

24. Xu H, Lu Z, Teng D, Wang J, Wang L, Li Z. Assessment of glomerular filtration rate in renal transplant patients using serum cystatin C. Transpl Proceed 2006; 38: 2006-8.

25. Donadiy C, Lucchesi A, Ardini M, Giordani R. Cystatin C, B2 microglobulin, and retinol binding proteins as indicators of glomerular filtration rate: comparison with plasma creatinine. J Pharm Biom Anal 2001; 24: 835-42.

26. Kyhse-Andersen J, Schmidt C, Nordin G, Andersson B, Nilsson-Ehle P, Lindstrom V. Serum cystatin C, determined by a rapid, automated particle-enhanced turbidimetric method, is a better marker than serum creatinine for glomerular filtration rate. Clin Chem 1994; 40: 1921-6.

27. Hoeck FJ, Kemperman FA, Krediet RT. A comparison between cystatin C, plasma creatinine and the Cockcroft and Gault formula for the estimation of glomerular filtration rate. Nephrol Dial Transplant 2003; 18: 2024-31.

28. Grubb A, Bjork J, Lindstrom V, Strerner G, Bondesson P, Nyman U. A cystatin C-based formula without anthropometric variables estimates glomerular filtration rate better than creatinine clearance using the Cockcroft-Gault formula. Scand J Clin Lab Invest 2005; 65: 153-62.

29. Rodrigo E, Fernandez-Fresnedo G, Castaneda O, Arias $M$. Estimation of renal function in adult kidney transplant recipients by equations. Transplant Rew 2007; 21: 1-16.

30. Hojs R, Bevc S, Ekart R, Gorenjak M, Puklavec L. Serum cystatin $C$ as an endogenous marker of renal function in patients with mild to moderate impairment of kidney function. Nephrol Dial Transpl 2006; 21: 1855-62. 